\title{
Catastrophic antiphospholipid syndrome (Asherson's syndrome) caused by a suspected intestinal neuroendocrine tumor: a case report
}

\author{
For citation: Gastroenterologia. 2021;55(3):206-210. doi: 10.22141/2308-2097.55.3.2021.241591
}

\begin{abstract}
Background. Every year, the number of people with rare forms of the disease is increasing worldwide. One of these is the catastrophic antiphospholipid syndrome - Asherson's syndrome. To date, it is being actively studied, but the pathophysiological mechanisms of its development have not yet been fully investigated. Our work is the first attempt to describe Asherson's syndrome on the example of a clinical case in Ukraine. Objective: to determine the factors and mechanisms that led to the death of a patient with Asherson's syndrome in Ukraine. Materials and methods. The structural-logical analysis and the clinical-statistical method were used. Results. Based on clinical and laboratory criteria, our medical team established a clinical diagnosis of systemic lupus erythematosus complicated by a catastrophic antiphospholipid syndrome (CAPS). Despite treatment with glucocorticoids and anticoagulants according to international guidelines, the patient died. The autopsy results showed that the immediate cause of death was a large blood clot that blocked the pulmonary artery and its main branches. Histological examination revealed thrombosis of small vessels of the kidneys and brain; a neuroendocrine tumor (G2; pT3pNxpM1b) of the small intestine with metastases to the liver, brain, myocardium and kidneys was suspected. An additional immunohistochemical study was performed to clarify the histological diagnosis. The morphological picture and results of immunohistochemical study mostly correspond to the moderately differentiated (G2) non-keratinizing squamous cell carcinoma (ICD-O code: 8070/3) with damage to the walls of the small intestine, liver, lungs, kidneys, myocardium and brain. Conclusions. These data emphasize that despite the rarity of Asherson's syndrome, it is always necessary to consider its probability in the presence of signs of multiple thrombosis and multiple organ failure. Because its development is the result of serious diseases, including connective tissue diseases, malignancies, infections, the etiotropic and pathogenetic treatment can prevent the development of CAPS and death.
\end{abstract}

Keywords: catastrophic antiphospholipid syndrome; systemic lupus erythematosus; squamous cell carcinoma

\section{Introduction}

The term "catastrophic antiphospholipid syndrome" (CAPS) was first described and introduced into medical terminology in 1992 by R. Asherson [1]. CAPS or Asherson's syndrome is the most severe variant of the antiphospholipid syndrome (APS) and is characterized by multiple thromboses and multiple organ failure with poor outcomes and a high rate of mortality. Approximately $1 \%$ of patients with classic APS develop CAPS, but with $37-50 \%$ of fatal outcomes $[2,3,6,19]$. In 2000, the international registry of patients with CAPS was created to investigate and develop clinical approaches and therapeutic guidelines in this condition [4]. Since 1992, it has been described approximately 500 cases of CAPS [5, 20], but there are no literature data about the registration of CAPS in Ukraine.

A precipitating factor of CAPS can be established in $50-65 \%$ of patients, and the most frequent is infection. In $10-16 \%$ of cases, CAPS is caused by malignancy $[3,5,6$, 19]. In this article, we described a clinical case of Asherson's syndrome caused by squamous cell carcinoma and probable systemic lupus erythematosus.

(c) 2021. The Authors. This is an open access article under the terms of the Creative Commons Attribution 4.0 International License, CC BY, which allows others to freely distribute the published article, with the obligatory reference to the authors of original works and original publication in this journal.

Для кореспонденції: Тіщенко Вікторія Вікторівна, кандидат медичних наук, доцент кафедри внутрішньої медицини № 1, бул. Т. Шевченка, 13, м. Київ, 01601, Україна; е-таі:: vtishchenk02@gmail.com; контактний тел.: +38(067)4059888

For correspondence: Viktoriya Tishchenko, PhD, Associated Professor at the Department of Internal Medicine 1, Bogomolets National Medical University, Taras Shevchenko Boulevard, 13, Kyiv, 01601, Ukraine; e-mail vtishchenk02@gmail.com; contact phone: +380674059888

Full list of authors information is available at the end of the article. 


\section{Case report}

A 40-year-old Caucasian woman presented to the neurological department of Kyiv City Clinical Hospital No. 18 (clinical base of Department of Internal Medicine No. 1 of Bogomolets National Medical University, Kyiv, Ukraine) with complaints of numbness and weakness in the right side of the face, right arm, pronounced general weakness, shakiness when walking, cough. Previous medical history: in 2012, a hysterectomy was performed for cervical cancer, followed by radiotherapy and chemotherapy. A month before her current admission, the patient took a course of antibiotics due to pneumonia, but cough and weakness have continued to bother. Physical examination revealed body temperature $38.5^{\circ} \mathrm{C}$, acrocyanosis, swelling of the right lower limb, arterial pressure $90 / 60 \mathrm{mmHg}$, heart rate $100 \mathrm{bpm}$, rhythmic pulse, dullness to percussion in basal parts of the lungs, bilaterally decreased breath sounds. Neurological examination revealed horizontal nystagmus, tongue deviation to the right, bilateral ataxia.

Initial laboratory investigations showed mild normocytic normochromic anemia, elevated erythrocyte sedimentation rate and $\mathrm{C}$-reactive protein, a decrease in urine density. Coagulogram (fibrinogen, prothrombin time and index, thrombin time, international normalized ratio) was normal. Electrocardiography showed sinus tachycardia with signs of P-pulmonale, short PQ syndrome. The deep venous thrombosis was excluded by duplex ultrasound of the lower extremities.

Computed tomography (CT) scan of the brain revealed small hyperdense inclusions of up to $3 \mathrm{~mm}$ in the frontoparietal regions of the brain. CT of the chest organs showed right atrial thrombus, pulmonary thrombosis, areas of lung tissue consolidation of $21 \times 36 \mathrm{~mm}$ in the $\mathrm{S} 2$ of the right lung (probably due to pulmonary embolism), liquid in the left pleural cavity and pericardial cavity, mediastinal lymphadenopathy. CT scan of the abdominal cavity, retroperitoneal space, and pelvis revealed multiple hypodense multifocal changes of up to $22 \mathrm{~mm}$ in the liver parenchyma, multiple multifocal changes in the spleen, multiple wedge-shaped perfusion defects in both kidneys, small amount of liquid in the retrovesical space, absence of uterus, supravesical lymphadenopathy (Fig. 1).

Magnetic resonance imaging of the brain revealed multiple irregular foci with fuzzy contours ranging from 3-6 to 9-12 mm in the cortical-subcortical regions of the left frontal, parietal, occipital, right frontal, and parietal lobes of the brain, in the left hemisphere of the cerebellum.

Due to the suspicion of systemic connective tissue disease and antiphospholipid syndrome, the patient was transferred to the therapeutic department for further examination and treatment under the supervision of the staff of the Department of Internal Medicine No. 1 of Bogomolets National Medical University (Kyiv, Ukraine). Additional laboratory investigations showed highly positive antinuclear antibodies $(1: 3200)$ and positive lupus anticoagulant (antiphospholipid antibodies). Based on previous medical history, current clinical picture, additional investigations data, as well as using SLICC [7] and CAPS criteria $[8,9]$, the clinical diagnosis of systemic lupus erythematosus (SLE) complicated by probable catastrophic antiphospholipid syndrome was made, but at the same time, the risk of recurrent cervical cancer with multiple metastases was not excluded. The treatment with glucocorticoids, parenteral anticoagulants (heparin), and then oral anticoagulants (warfarin) in appropriate and recommended doses was initiated under the control of the relevant indicators

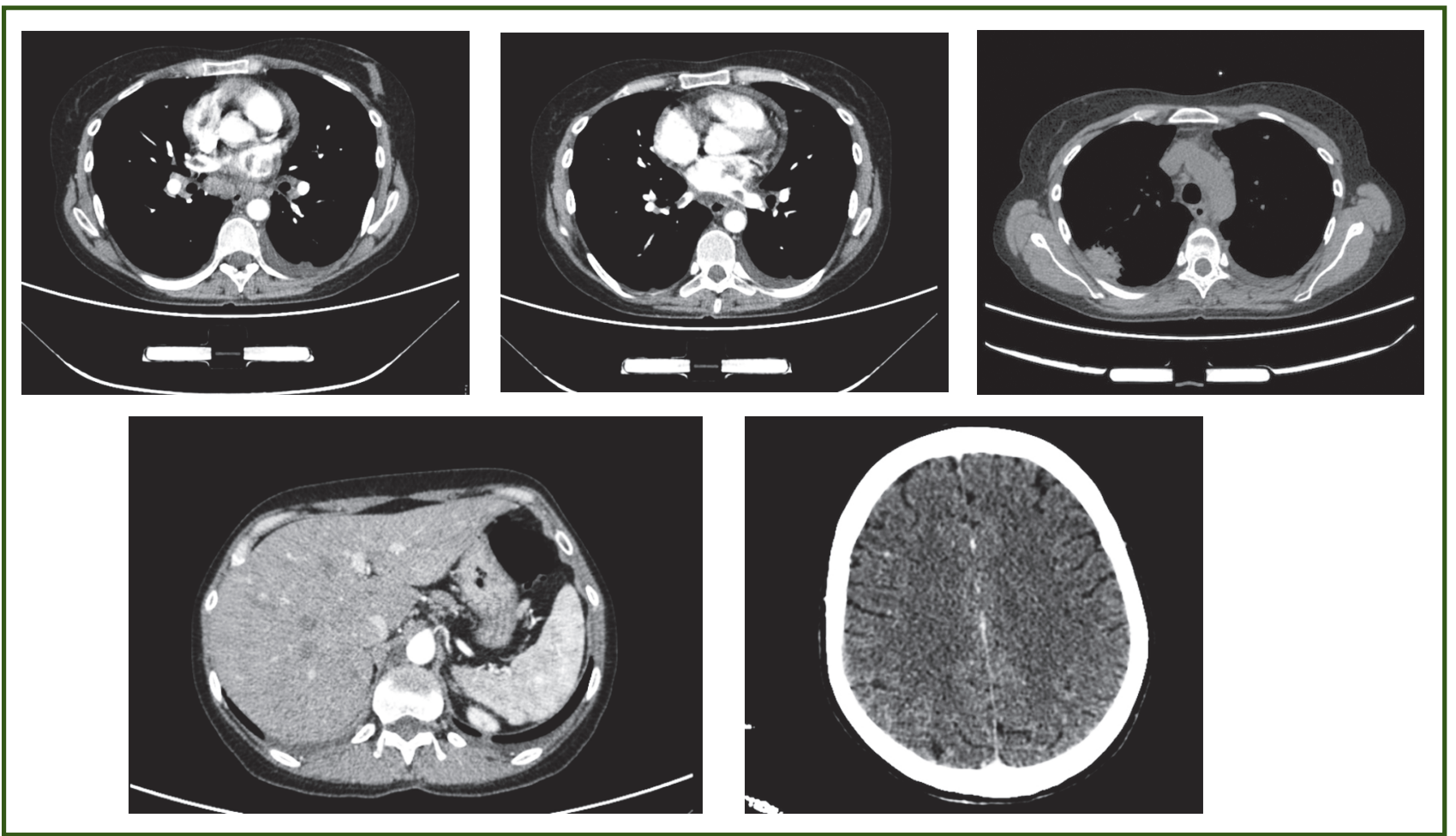

Figure 1-CT scans of the brain, organs of the chest and abdomen 
of coagulogram $[10,11]$. Within several days after the start of treatment, the patient noted a slight improvement in her condition, a decrease in temperature. But over the next 8 days, the woman had increased shortness of breath and general weakness. On day 12 of treatment, palpitations, severe shortness of breath, loss of consciousness, BP 70/30 $\mathrm{mmHg}$, heart rate $125 \mathrm{bpm}$ were detected. The patient was transferred to the intensive care unit with a preliminary diagnosis of high-risk acute pulmonary embolism, and emergency treatment was initiated [12]. Unfortunately, the patient died the next day.

The autopsy showed that the immediate cause of death was a large thromboembolus occluding the pulmonary artery and its main branches. Histological investigation revealed thrombosis of the small vessels of the kidneys and brain; a neuroendocrine tumor (G2; pT3pNxpM1b) of the small intestine with metastases to the liver, brain, myocardium, and kidneys was suspected. To clarify the histological diagnosis, an additional immunohistochemical study was conducted. The results were as follows: tumor cells turned out to be negative for chromogranin A and synaptophysin, which allows excluding the neuroendocrine origin of the tumor. Tumor cells were positive for general cytokeratin, cytokeratin 5, p40, and p63. The grade of nuclear pleomorphism is moderate. Signs of keratinization are not detected. The morphological picture and the results of immunohistochemical investigation most closely correspond to a moderately differentiated $(\mathrm{G} 2)$ non-keratinizing squamous cell carcinoma (ICD-O code: $8070 / 3$ ) with damage to the wall of the small intestine, liver, lung, kidney, myocardium, and brain (Fig. 2). However, the localization of the primary tumor remained unknown (probably, it was cervical cancer).

\section{Discussion}

To the present day, the pathophysiological mechanisms of CAPS development are not fully understood, which is associated with a rather rare occurrence of this syndrome, especially in cancer patients, but the concept of thrombotic storm was proposed [11, 13]. Different malignancies are associated with the presence and production of antiphospholipid

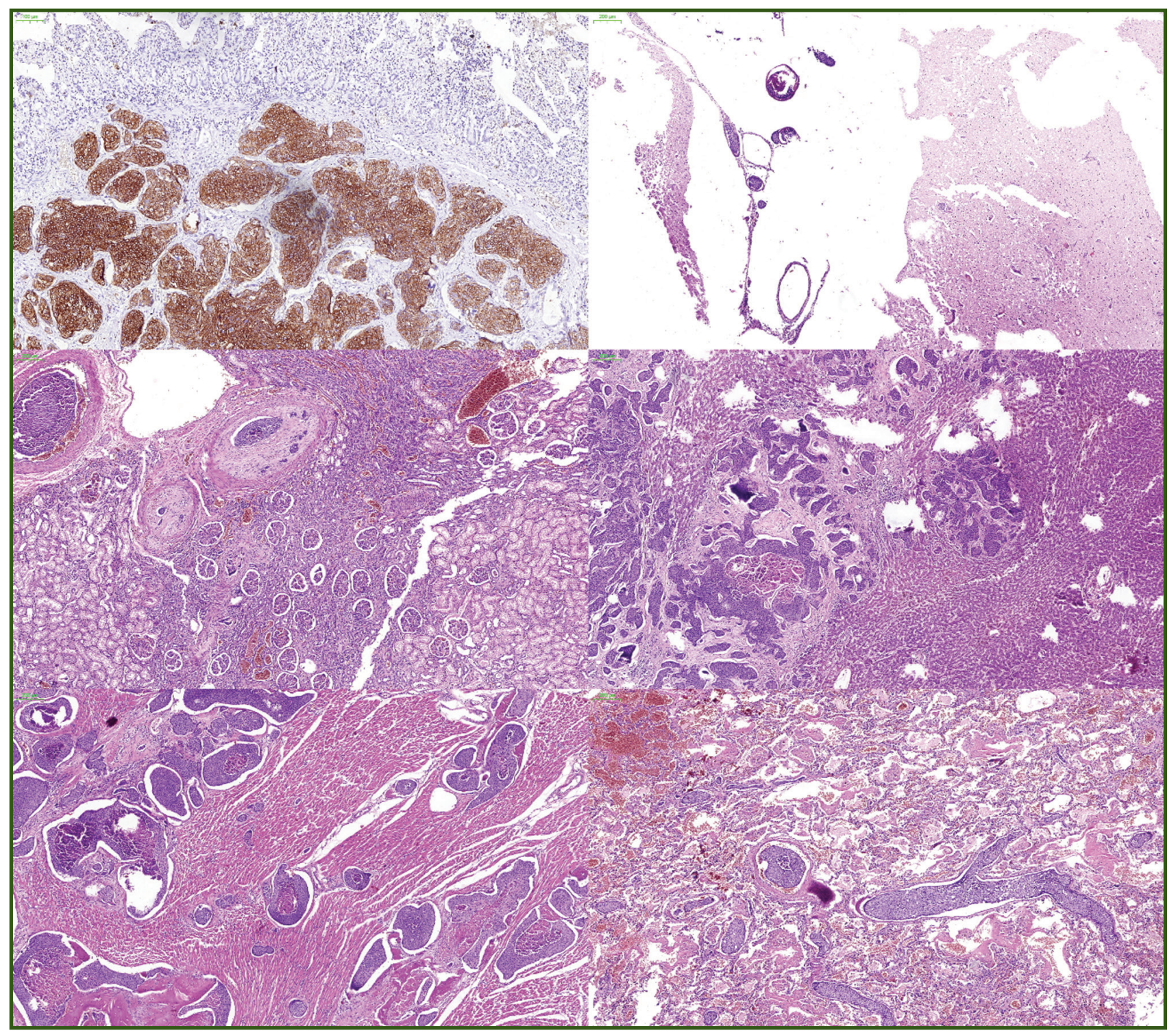

Figure 2 - Results of histological and immunohistochemical investigation of the small intestine, brain, kidneys, liver, myocardium, and lungs 
antibodies followed by the launch of the thrombophilic cascade and further development of APS and CAPS [6, 14, 18]. The clinical picture of CAPS requires a differential diagnosis with sepsis, thrombotic thrombocytopenic purpura, hemolytic uremic syndrome, acute disseminated intravascular coagulation and haemolysis, elevated liver enzymes, and low platelet syndrome $[11,15]$.

In this article, we presented a clinical case in a patient with the clinical diagnosis of SLE complicated by CAPS, but further investigation of autopsy material didn't reveal the histological signs of SLE (lupus nephritis) [8]. On the other hand, there were multiple foci of the moderately differentiated non-keratinizing squamous cell carcinoma, which, in our opinion, probably were metastasis of cervical cancer. We assume that the main trigger factor in the development of CAPS in this patient was squamous cell carcinoma. However, we cannot explain such a high antinuclear antibodies titer even though some tumors may be accompanied by an increase of these antibodies [16, 17]. Therefore, the question remains open for us whether the patient had systemic lupus erythematosus or not. In our opinion, it is possible that SLE could act as another triggering and complicating factor. Furthermore, according to literature data, the high titer of antinuclear antibodies is associated with a higher mortality rate [15].

\section{Conclusions}

This clinical case of Asherson's syndrome is first described in Ukraine. Its practical significance lies in the fact that, despite rare occurrence, it is always necessary to consider its likelihood in the presence of signs of multiple thromboses and multiple organ failure. Since its development is a consequence of serious diseases, including connective tissue diseases, malignancies, infections, the etiotropic and pathogenetic treatment can prevent the development of CAPS and death.

\section{References}

1. Asherson RA. The catastrophic antiphospholipid syndrome. J Rheumatol. 1992 Apr;19(4):508-12.

2. Cervera R, Piette JC, Font J, et al; Euro-Phospholipid Project Group. Antiphospholipid syndrome: clinical and immunologic manifestations and patterns of disease expression in a cohort of 1,000 patients. Arthritis Rheum. 2002 Apr;46(4):1019-27. doi: 10.1002/ art.10187.

3. Bucciarelli $S$, Espinosa $G$, Cervera $R$, et al; European Forum on Antiphospholipid Antibodies. Mortality in the catastrophic antiphospholipid syndrome: causes of death and prognostic factors in a series of 250 patients. Arthritis Rheum. 2006 Aug;54(8):2568-76. doi: 10.1002/art.22018.

4. Cervera R. CAPS Registry. Lupus. 2012 Jun;21(7):755-7. doi: 10.1177/0961203312436866.

5. Rodríguez-Pintó I, Moitinho M, Santacreu I, et al; CAPS Registry Project Group (European Forum on Antiphospholipid Antibodies). Catastrophic antiphospholipid syndrome (CAPS): Descriptive analysis of 500 patients from the International CAPS Registry. Autoimmun Rev. 2016 Dec;15(12):1120-1124. doi: 10.1016/j.autrev.2016.09.010.

6. Miesbach W. Malignancies and catastrophic anti-phospholipid syndrome. Clin Rev Allergy Immunol. 2009 Jun;36(2-3):91-7. doi: 10.1007/s 12016-008-8101-2.

7. Petri M, Orbai AM, Alarcón GS, et al. Derivation and validation of the Systemic Lupus International Collaborating Clinics classification criteria for systemic lupus erythematosus. Arthritis Rheum. 2012 Aug;64(8):2677-86. doi: 10.1002/art.34473.

8. Asherson RA, Cervera $R$, de Groot $P G$, et al; Catastrophic Antiphospholipid Syndrome Registry Project Group. Catastrophic antiphospholipid syndrome: international consensus statement on classification criteria and treatment guidelines. Lupus. 2003;12(7):530-4. doi: 10.1191/0961203303lu394oa.

9. Cervera R, Font J, Gómez-Puerta JA, et al; Catastrophic Antiphospholipid Syndrome Registry Project Group. Validation of the preliminary criteria for the classification of catastrophic antiphospholipid syndrome. Ann Rheum Dis. 2005 Aug;64(8):1205-9. doi: 10.1136/ard.2004.025759.

10. Legault K, Schunemann H, Hillis C, et al. McMaster RA$R E$-Bestpractices clinical practice guideline on diagnosis and management of the catastrophic antiphospholipid syndrome. J Thromb Haemost. 2018;16(8): 1656-1664. doi: 10.1111/jth.14192.

11. Carmi O, Berla M, Shoenfeld Y, Levy Y. Diagnosis and management of catastrophic antiphospholipid syndrome. Expert Rev Hematol. 2017 Apr;10(4):365-374. doi: 10.1080/17474086.2017.1300522.

12. Konstantinides SV, Torbicki A, Agnelli G, et al; Task Force for the Diagnosis and Management of Acute Pulmonary Embolism of the European Society of Cardiology (ESC). 2014 ESC guidelines on the diagnosis and management of acute pulmonary embolism. Eur Heart J. 2014 Nov 14;35(43):3033-69, 3069a-3069k. doi: 10.1093/ eurheartj/ehu283.

13. Kitchens CS. Thrombotic storm: when thrombosis begets thrombosis. Am J Med. 1998 Apr;104(4):381-5. doi: 10.1016/s00029343(98)00061-8.

14. Asherson RA. Antiphospholipid antibodies, malignancies and paraproteinemias. J Autoimmun. 2000 Sep;15(2):117-22. doi: 10.1006/jaut.2000.0404.

15. Sciascia S, Lopez-Pedrera C, Roccatello D, Cuadrado MJ. Catastrophic antiphospholipid syndrome (CAPS). Best Pract Res Clin Rheumatol. 2012 Aug;26(4):535-41. doi: 10.1016/j. berh.2012.07.005.

16. Heegaard NH, West-Nørager M, Tanassi JT, et al. Circulating antinuclear antibodies in patients with pelvic masses are associated with malignancy and decreased survival. PLoS One. 2012;7(2):e30997. doi: 10.1371/journal.pone.0030997.

17. Fernández-Madrid F, VandeVord PJ, Yang X, et al. Antinuclear antibodies as potential markers of lung cancer. Clin Cancer Res. 1999 Jun;5(6):1393-400.

18. Özgür $G$, Beyan $C$. Therapeutic apheresis in the treatment of catastrophic antiphospholipid syndrome. Transfus Apher Sci. 2018 Feb;57(1):13-15. doi: 10.1016/j.transci.2018.02.008.

19. Rodriguez-Pintó I, López-Benjume B, Espinosa G, Cervera $R$. Catastrophic antiphospholipid syndrome. Revista Colombiana de Reumatología. 2021 Jun;28(Suppl 1):39-43. doi: 10.1016/j. rcreu.2021.02.004.

20. Ruffatti A, De Silvestro G, Marson P, et al. Catastrophic antiphospholipid syndrome: Lessons from 14 cases successfully treated in a single center. A narrative report. J Autoimmun. 2018 Sep;93:124130. doi: 10.1016/j.jaut.2018.07.001.

Received 13.06.2021

Revised 28.06.2021

Accepted 06.07.2021 


\section{Information about authors}

V.P. Shypulin, MD, PhD, Professor, Head of the Department of Internal Medicine 1, Bogomolets National Medical University, Kyiv, Ukraine; e-mail: shypulin@me.com; https://orcid.org/0000-0002-6780-130X V.V. Cherniavskyi, MD, PhD, Professor of the Department of Internal Medicine 1, Bogomolets National Medical University, Kyiv, Ukraine; e-mail:Vvch1979@gmail.com; https://orcid.org/0000-0001-5831-8810 L.S. Hvozdecka, PhD, Associate Professor of the Department of Internal Medicine 1, Bogomolets National Medical University, Kyiv, Ukraine; e-mail: lesyasg@ukr.net; https://orcid.org/0000-0002-3973-762X A.V. Neverovskyi, PhD Candidate, Department of Internal Medicine 1, Bogomolets National Medical University, Kyiv, Ukraine; e-mail: ArtemNeverovskiy@gmail.com; https://orcid.org/0000-0002-2618-6347 V.V. Tishchenko, PhD, Associate Professor at the Department of Internal Medicine 1, Bogomolets National Medical University, Kyiv, Ukraine; e-mail: vtishchenko2@gmail.com; https://orcid.org/0000-0002-4157-4428

Conflicts of interests. Authors declare the absence of any conflicts of interests and their own financial interest that might be construed to influence the results or interpretation of their manuscript. Funding information. This research received no specific funding or grant during its writing.

Шипулін В.П., Чернявський В.В., ГвозАецька А.С., Неверовський А.В., Тіщенко В.В.

Національний меАичний університет імені О.О. Богомольця, м. Київ, Україна

\section{Катастрофічний वнтифосфОАіпіАний синАром (синАром Ашерсонव), обумовлений ймовірною нейроенАОКрИнНОю ПУХАинОю КИшечника: випаАОК із практики}

Резюме. Актуальність. Щороку в усьому світі кількість людей із рідкісними формами хвороб збільшується. Однією з них $€$ катастрофічний антифосфоліпідний синдром - синдром Ашерсона. На сьогодні він активно досліджується, однак патофізіологічні механізми його розвитку ще не вивчені до кінця. Наша робота є першою спробою опису синдрому Ашерсона на прикладі клінічного випадку в Україні. Мета: визначення факторів і механізмів, що призвели до смерті пацієнта з синдромом Ашерсона в Україні. Матеріали та методи. Під час роботи використані структурно-логічний аналіз і клініко-статистичний метод. Результати. На основі комплексу клінічних і лабораторних критеріїв наша медична група поставила пацієнту клінічний діагноз системного червоного вовчака, ускладненого катастрофічним антифосфоліпідним синдромом. Незважаючи на лікування глюкокортикоїдами та антикоагулянтами відповідно до міжнародних рекомендацій, пацієнт помер. Результати розтину показали, що безпосередньою причиною смерті став великий тромб, який закупорював легеневу артерію та їі основні гілки. При гістологічному дослідженні було виявлено тромбоз дрібних судин нирок і мозку, підозрювали нейроендокринну пухлину (G2; pT3pNxpM1b) тонкої кишки 3 метастазами в печінку, мозок, міокард та нирки. Для уточнення гістологічного діагнозу було проведене додаткове імуногістохімічне дослідження. Морфологічна картина і результати імуногістохімічного дослідження найбільше відповідають помірно диференційованому (G2) незроговілому плоскоклітинному раку (код MKX-O: 8070/3) із пошкодженням стінок тонкої кишки, печінки, легенів, нирок, міокарда та мозку. $\boldsymbol{B u}$ сновки. Наведені дані підкреслюють, що, незважаючи на рідкість синдрому Ашерсона, завжди необхідно враховувати його ймовірність у разі ознак множинного тромбозу та поліорганної недостатності. Оскільки його розвиток є наслідком серйозних захворювань, серед яких захворювання сполучної тканини, злоякісні утворення, інфекції, етіотропне та патогенетичне лікування може запобігти розвитку катастрофічного антифосфоліпідного синдрому та смерті.

Ключові слова: катастрофічний антифосфоліпідний синдром; системний червоний вовчак; плоскоклітинний рак 